\title{
A COMPARATIVE STUDY OF APICAL TRANSPORTATION AND STRAIGHTENING OF TWO ROTARY NICKEL-TITANIUM SYSTEMS WHEN USING FINAL APICAL BRUSHING
}

\author{
Heba A. Abdalla ${ }^{I} B D S$, Sybel M. Moussa $S^{2} P h D$, Nayera A. Mokhless $N^{3} P h D$
}

\begin{abstract}
INTRODUCTION: Apical transportation results in an inadequately clean apical area and makes apical seal more difficult thus affecting the final outcome and may lead to failure.

OBJECTIVES: The aim of this study was to compare between the effect of two rotary nickel titanium systems after using final apical strokes on canal transportation and apical straightening of the canal.

MATERIALS AND METHODS: Sixty mesiobuccal canals of extracted mandibular first molars with root canal curvature angle (25 to 45 degree) were selected. Canals were divided into two groups $(n=30)$. In group I canals were prepared with OneShape file, while in group II, canals were prepared with Revo-S system. Each group was then sub-divided into two sub-groups according to the motion used (pecking or circumferential filing). Sub group Ia (OneShape file) and sub group Ib (Revo-S system) were prepared with pecking motion while sub group II an and sub group II b were prepared with circumferential filing motion. A radiographic platform was used to obtain accurate radiographs. All specimens were radiographed from proximal and mesiodistal views. To measure apical transportation, the pre and post-instrumentation radiographs were exported from the Kodak software into Photoshop program. Then a grading system was used to assess the amount of transportation. Based on apical curvature measured before and after instrumentation (using Image J program), canal straightening was determined as the difference between these two measurements.

RESULTS: Regarding apical transportation, no statistical significance was found between both groups and the sub groups. Apical straightening was evaluated, and no statistical significance was found between the groups. However, circumferential filing produced more straightening. CONCLUSIONS: OneShape file and Revo-S system maintained the original canal curvature with no significant differences between the files. Circumferential filing motion with both systems resulted in higher values of straightening when compared to pecking motion. KEYWORDS: Apical canal transportation, canal straightening, rotary nickel titanium, single file.
\end{abstract}

1- Assistant lecturer, Endodontics, Department of Conservative Dentistry, Faculty of Dentistry, Alexandria University, Alexandria, Egypt

2- Professor of Endodontics, Department of Conservative Dentistry, Faculty of Dentistry, Alexandria University, Alexandria, Egypt

3- Assistant Professor of Endodontics, Department of Conservative Dentistry, Faculty of Dentistry, Alexandria University, Alexandria, Egypt

\section{INTRODUCTION}

Root canal shaping is one of the most important procedures in endodontic treatment. The main goal is to debride the pulp cavity completely and enlarge the root canal system for ease of obturation, while maintaining the original canal configuration.

Apical transportation results in an inadequately clean apical area and makes apical seal more difficult thus affecting the final outcome and may lead to failure. This can occur during canal preparation due to tendency of the files to restore themselves to their original linear shape leading to removal of canal wall structure on the outside curve in the apical half of the canal ${ }^{(1)}$.

Several techniques have been used for the assessment of canal instrumentation, such as scanning electron microscope, radiographic evaluation and photographic assessment. Double- digital radiographic techniques are currently used for assessment of canal transportation. These techniques are easy to use, inexpensive and potentially informative ${ }^{(2,3)}$.

Over the years, many nickel titanium rotary instruments have been developed to improve root canal preparation owing to their super-elastic properties. They are available in various designs that differ in tip and taper design, rake angles, helical angles, pitch and presence of radial lands. The use of NiTi instruments decreased the prevalence and degree of root canal transportation compared with hand instruments ${ }^{(4)}$.

Older rotary systems adapted a crown down technique preparation that includes pre-flaring prior to apical preparation using a sequence of three to four instruments.

The Revo-S system is a novel rotary system intended for endodontic treatment by crown down technique with only three instruments. The asymmetrical cross section of the Revo-S facilitates penetration by snake-like movement and offers a root canal shaping adapted to the biological and ergonomic imperatives ${ }^{(5)}$.

Recently, single file endo concept was introduced. Single file requires a minimum or no glide path and only a single file for complete instrumentation for majority of root canals. The recommendation for single use has added the advantage of reducing instrument fatigue and lower cross contamination between the patients ${ }^{(6)}$.

One Shape is a single nickel titanium file used in continuous rotation for better quality of canal preparation. This file allows for better negotiation of curved canals with an instrumental and easy dynamic. The instrument with three different cross section zones is guided down the glide path by three cutting edges providing flexibility and assuring a perfect respect to the original canal path, thus decreasing the risk of apical transportation ${ }^{(7)}$.

In both systems (Revo-S and OneShape) slight pecking motion is recommended for use. The manufacturers claim 
that upon reaching the apical portion with the last used instrument, brushing motion could be used for circumferential filing for further flaring of the canal.

However, the effect of repeatedly using this circumferential filing motion on apical transportation is still under investigation. The null hypothesis of this study was that circumferential filing after reaching the apical limit might increase apical transportation.

\section{MATERIALS AND METHODS}

This study was conducted following the requirements of the Institutional Review Board (IRB) of the faculty of dentistry, Alexandria University regarding research involving human tissues.

This study was conducted on sixty curved mesiobuccal root canals of extracted human mandibular molars that were extracted due to impactions or periodontal disease.

\section{Preparation of the specimens}

The distal roots were removed using a high speed tapered diamond bur at the furcation level, for ease of introduction into the plastic cubes and superimposition of the radiographs.

Endodontic access cavities were prepared in all molars using a \#4 round-end diamond bur (Komet, gebr, Brasseler Gmbh \& co.) for the initial entry followed by Endo-Z (Dentsply Maillefer, Ballaigues, Switzerland) bur for lateral extension and finishing of the cavity walls. Access cavities were then irrigated with $2.5 \%$ sodium hypochlorite to flush away debris and coronal pulp tissue. An endodontic explorer was used to explore the canal orifices and to evaluate a straight line access. The cusp tips were ground flat to achieve a stable reference point for the files. A \# 10 $\mathrm{K}$ file was introduced into the mesiobuccal canals until just visible at the apical foramen to ensure apical patency, and one $\mathrm{mm}$ was subtracted from this measurement to establish the working length. The apical foramen of each root was sealed with wax to prevent resin penetration while embedding the tooth in the resin. The resin blocks were prepared using 60 identical plastic cubes. These plastic cubes were prepared to receive the tooth and resin, and each has a protrusion to fit into the plastic base of a radiographic platform.

\section{Digital evaluation of apical transportation}

A radiographic platform was fabricated to allow accurate pre- and post-instrumentation radiographs to be taken in the same position.

\section{Pre-instrumentation radiographs}

Standardized digital pre-instrumentation radiographs were taken for each tooth in a bucco-lingual and proximal direction with the initial file inserted up to the exact working length using the radiographic platform and Kodak RVG digital radiography system. Kodak dental imaging software was used to display and save the radiographs in a specific file for each tooth.

Measuring canal curvature using Schneider's technique (8) The pre-instrumentation radiograph of each tooth was exported from Kodak software to Image J (Image-J v1.44; Us national Institutes of Health, Bethesda, MD, USA). A line was scribed parallel to the long axis of the canal. A second line was drawn from the apical foramen to intersect the first line at the point where the canal began to leave the long axis of the root. The acute angle thus formed was measured using the angle tool feature of the Image $\mathbf{J}$ program. Only canals whose angle of curvature ranged between 25 degrees and 45 degrees were included.

Guidelines for instrumentation of the canals Manual preflaring of all the canals with stainless steel K-files \# 15 and \# 20 was done to the full working length to create a glide path before using $\mathrm{Ni}-\mathrm{Ti}$ rotary instrumentation. Copious irrigation was performed between the use of each file during the instrumentation procedure with freshly prepared $2.5 \% \mathrm{NaOCl}$ using a 27 -gauge needle placed into the canal without binding after each successive enlargement of the canal for both techniques. A \# $10 \mathrm{~K}$ file was inserted after each file to check apical patency. File-Eze (Ultradent, USA) was used as a lubricating and chelating agent before and during the use of each instrument to facilitate preparation. Endoflare rotary file (Micro-Mega Besancon cedex, France) was inserted inside the canal $3 \mathrm{~mm}$ below the pulp chamber floor to remove all coronal constrictions.

Mesiobuccal canals of all teeth in group I were instrumented using OneShape files (Micro-Mega Besancon cedex, France). The OneShape file was operated with 350 rpm speed of rotation and 4 N.cm torque. The file was placed down to the two-thirds of the working length using in and out movement without pressure with an amplitude of three $\mathrm{mm}$. The file was then withdrawn from the root canal, cleaned and the canal was irrigated and canal patency checked with \# $10 \mathrm{~K}$ file. The file was introduced again into the root canal and placed down to $3 \mathrm{~mm}$ from the working length, then withdrawn and cleaned again. In sub group Ia the file was then re-introduced into the root canal and taken down to the working length with supplemental slight pecking motion. In sub group $\mathrm{Ib}$, upward circumferential filing motion was performed to the full working length. In group I, the file was discarded after the preparation of each root canal.

Mesiobuccal canals of all teeth in group II were instrumented using Revo-S nickel-titanium rotary files (Micro-Mega Besancon cedex, France. The Revo-S file was operated with $350 \mathrm{rpm}$ speed of rotation and $0.8 \mathrm{~N} . \mathrm{cm}$ torque. File SC1 (tip size 25 and taper 6\%) was inserted to two- thirds the working length to prepare the middle third. The canal was irrigated and patency checked with \# $10 \mathrm{~K}$ file. File SC2 (tip size 25 and taper 4\%) was used to full working length. Again, the canal was irrigated and patency checked with file \# $10 \mathrm{~K}$ file. File SU (tip size 25 and taper $6 \%$ ) was used to full working length with supplemental slight pecking motion for group II a. For sub group II b, upward circumferential movement was performed to the full working length. In group II, the files were discarded after the preparation of four root canals according to the manufacturer's instructions.

\section{Post-instrumentation radiographs}

Standardized digital post-instrumentation radiographs were taken in a bucco-lingual and proximal direction with the aid of the radiographic platform and with the master file inside the canal up to the exact working length using Kodak RVG digital radiography system. The post-instrumentation radiograph was displayed then stored in the specific file of each tooth with its pre-instrumentation one.

\section{Grading of apical transportation}

(9) The pre- and post-instrumentation radiographs for each tooth were exported from the Kodak software into Photoshop program (Adobe systems, San Jose, CA, USA). The apical portions of the initial and master apical files were selected and colored each with a different color using the 
Photoshop tools, the pre- and post-instrumentation radiographs were superimposed, the metallic L-shaped wire reference object and the root outline were used to achieve superimposition of the radiographs.

No transportation (0): Complete superimposition in the apical $2 \mathrm{~mm}$ of the master apical file so that the initial file falls within the confines of the master apical file.

Mild transportation (1): Slight shift of the superimposed files.

Moderate transportation (2): There is still contact in the apical $2 \mathrm{~mm}$ of the divergent files.

Severe transportation (3): No superimposition in the apical $2 \mathrm{~mm}$ of the superimposed files.

Apical transportation was recorded from buccal and proximal views.

\section{Measuring the degree of apical canal straightening}

Based on apical canal curvature measured before and after instrumentation, apical canal straightening was determined as the difference between these two measurements according to Hulsmann and Styrga technique ${ }^{(10)}$ as follows:

Measuring pre-instrumentation apical canal curvature Pre-instrumentation radiograph of each tooth was exported from Kodak software into Image $J$ program. An axis was drawn along the main part of the root canal as proposed by Schneider. (This main axis was used as a reference for the following post-instrumentation measurement). A second axis was drawn along the apical two $\mathrm{mm}$ of the initial file to the main axis (which is a slight modification of the Schneider's technique). The angle thus formed was measured by the angle tool feature of the Image $\mathrm{J}$ to determine the pre-instrumentation apical curvature.

Measuring post-instrumentation apical canal curvature Post-instrumentation radiograph of each tooth was exported from Kodak software to Image J and superimposed over its pre-instrumentation one guided by the L shaped orthodontic reference wire and the root outline.

An axis was drawn along the apical two mm of the master apical file to the reference axis and the angle thus formed was measured using the angle tool feature of the Image $J$ to determine the post-instrumentation apical canal curvature. Apical canal straightening for each tooth was determined as the difference between the pre- and post-instrumentation apical canal curvatures. Apical canal straightening was calculated from buccal and proximal views.

\section{STATISTICAL ANALYSIS}

After data were collected it was revised, coded and fed to statistical software SPSS IBM version 20. The given graphs were constructed using Microsoft excel software. All statistical analysis was done using two tailed tests and alpha error of 0.05 . Descriptive statistics in the form of frequencies and percent were used to describe the categorical data while mean and standard deviation for numeric data which follow normal distribution, nonparametric statistics were used. To test for association between groups at different phases, Mont Carlo exact test was the preferred. Non parametric Mann-Whitney test was used to compare means between the two groups at different views.

\section{RESULTS}

Grading of apical transportation (figure 1) In this study there was no statistical significant differences between subgroup I am (ONESHAPE pecking) and sub group I b
(ONESHAPE circumferential filing) in buccal view at $\mathrm{P}<0.05(\mathrm{P}=0.078)$.

Sub group I am (OneShape with pecking motion) showed equal distribution of apical transportation between the scores of no, mild and moderate, but severe transportation was not observed (Table 1). In sub group I b (OneShape) with circumferential filing), the highest percentage was seen with mild apical transportation in $(53.30 \%)$ of the cases, while severe transportation has been observed in $(6.70 \%)$ of the cases.

Also, no statistically significant difference was found between sub group II a (Revo-S pecking) and sub group II $\mathrm{b}$ (Revo-S circumferential filing) in buccal view at $\mathrm{P}<0.05$ $(\mathrm{P}=0.826)$. In sub group II a (Revo-S with pecking), 33.3\% of

the cases showed no transportation and the same percentage has been observed for moderate transportation. Severe transportation was traced in $6.75 \%$ of the cases, while mild transportation was seen in $26.7 \%$ of the cases (Table 1). Meanwhile, in sub group II b (Revo-S with circumferential filing), the same percentage of $26.7 \%$ has been observed in both no and moderate transportation. Severe transportation has been seen in a percentage of $13.3 \%$ while mild transportation showed the highest occurrence of $33.3 \%$. (Table 1)

No statistical significant difference was found between subgroup I am (ONESHAPE pecking) and sub group I b (ONESHAPE circumferential filing) in proximal view at $\mathrm{P}<0.05(\mathrm{P}=00.163)$ (Table 2).

The percentage of cases having no transportation in sub group II a (Revo-S pecking) and II b (Revo-S circumferential filing) was $33.3 \%$ (five cases) and $20.0 \%$ (three cases) respectively, cases with mild transportation was $33.3 \%$ (five cases) and $33.3 \%$ (five cases) respectively, cases with moderate transportation was $26.7 \%$ (four cases) and $46.7 \%$ (seven cases) respectively and cases with sever transportation the percentage was $6.7 \%$ (one case) and $0.0 \%$ respectively (Table 2 ).

By using the Mont Carlo exact test, there was no statistical significant difference between sub group II a (Revo-S pecking) and II $b$ (Revo-S circumferential filing) in the proximal view at $\mathrm{P}<0.05(\mathrm{P}=0.549)$. (Table 2$)$

By using the Mont Carlo exact test, there was no statistical significant difference between group I (ONESHAPE) and group II (Revo-S) in the proximal view (Table 2 ).
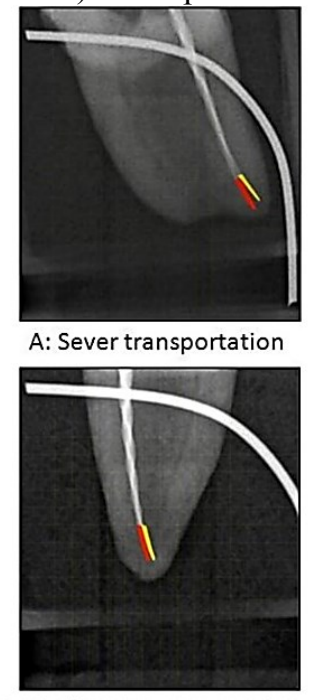

C: Moderate transportation
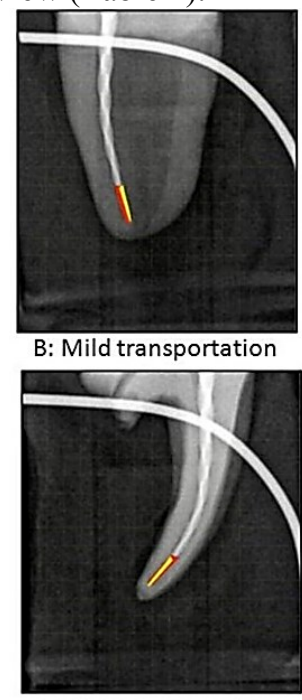

D: No transportation
Figure 1: Grading of apical transportation. 
Table (1): Grading of apical transportation in buccal view for both groups.

\begin{tabular}{|c|c|c|c|c|c|c|c|}
\hline \multirow[b]{2}{*}{ View } & \multirow[b]{2}{*}{ Group } & \multirow[b]{2}{*}{ Grade } & \multicolumn{4}{|c|}{ File motion } & \multirow[b]{2}{*}{$\begin{array}{c}\text { MC } \\
\mathbf{P}\end{array}$} \\
\hline & & & $\begin{array}{r}P \\
\text { No } \\
(n \\
=1 \\
5)\end{array}$ & $\begin{array}{l}\text { king } \\
\qquad \%\end{array}$ & $\begin{array}{c}\text { Circ } \\
\text { No } \\
(n=15\end{array}$ & $\begin{array}{l}\text { rential } \\
\text { g } \\
\quad \%\end{array}$ & \\
\hline \multirow{2}{*}{ Buccal } & $\begin{array}{c}\text { Group I } \\
\text { ONESHAPE }\end{array}$ & $\begin{array}{c}\text { No (0) } \\
\text { Mild (1) } \\
\text { Moderate } \\
\text { (2) } \\
\text { Severe } \\
\text { (3) }\end{array}$ & $\begin{array}{l}5 \\
5 \\
5 \\
0\end{array}$ & $\begin{array}{c}33.30 \\
\% \\
33.30 \\
\% \\
33.30 \\
\% \\
0.00 \\
\%\end{array}$ & $\begin{array}{l}3 \\
1\end{array}$ & $\begin{array}{l}20.00 \% \\
53.30 \% \\
20.00 \% \\
6.70 \%\end{array}$ & 0.078 \\
\hline & $\begin{array}{l}\text { Group II } \\
\text { Revo-S }\end{array}$ & $\begin{array}{c}\text { No (0) } \\
\text { Mild (1) } \\
\text { Moderate } \\
\text { (2) } \\
\text { Severe } \\
\text { (3) }\end{array}$ & $\begin{array}{l}5 \\
4 \\
5 \\
1\end{array}$ & $\begin{array}{c}33.30 \\
\% \\
26.70 \\
\% \\
33.30 \\
\% \\
6.70 \\
\%\end{array}$ & 4 & $\begin{array}{l}26.70 \% \\
33.30 \% \\
26.70 \% \\
13.30 \%\end{array}$ & 0.826 \\
\hline \multicolumn{3}{|c|}{ МCP } & \multicolumn{2}{|c|}{0.774} & \multicolumn{2}{|c|}{0.726} & \\
\hline
\end{tabular}

Table (2): Grading of apical transportation in proximal view.

\begin{tabular}{|c|c|c|c|c|c|c|}
\hline \multirow{3}{*}{ View } & \multirow{3}{*}{ Group } & \multirow{3}{*}{ Grade } & \multicolumn{3}{|c|}{ File motion } & \multirow{3}{*}{ МСР } \\
\hline & & & \multicolumn{2}{|c|}{ Pecking } & $\begin{array}{l}\text { Circumferen } \\
\text { tial filing }\end{array}$ & \\
\hline & & & $\begin{array}{c}\text { No } \\
(n=15)\end{array}$ & $\%$ & $\begin{array}{c}\text { No } \\
(\mathrm{n}=15 \\
)\end{array}$ & \\
\hline \multirow{8}{*}{ Proximal } & \multirow{4}{*}{$\begin{array}{c}\text { Group I } \\
\text { ONESHAPE }\end{array}$} & No $(0)$ & 7 & 46.7 & 26. & \multirow{4}{*}{0.163} \\
\hline & & Mild (1) & & $\begin{array}{c}20.0 \\
\%\end{array}$ & $\begin{array}{l}20 . \\
0 \%\end{array}$ & \\
\hline & & $\begin{array}{l}\text { Moderate } \\
\text { (2) }\end{array}$ & 5 & $\begin{array}{c}33.3 \\
\%\end{array}$ & $\begin{array}{l}40 . \\
0 \%\end{array}$ & \\
\hline & & Severe (3) & 0 & $0.0 \%$ & $\begin{array}{l}13 . \\
3 \%\end{array}$ & \\
\hline & \multirow{4}{*}{$\begin{array}{l}\text { Group II } \\
\text { Revo-S }\end{array}$} & No (0) & 5 & $\begin{array}{c}33.3 \\
\%\end{array}$ & $\begin{array}{l}20 . \\
0 \%\end{array}$ & \multirow{4}{*}{0.549} \\
\hline & & Mild (1) & 5 & $\begin{array}{c}33.3 \\
\%\end{array}$ & $\begin{array}{l}33 . \\
3 \%\end{array}$ & \\
\hline & & $\begin{array}{l}\text { Moderate } \\
\text { (2) }\end{array}$ & & $\begin{array}{c}26.7 \\
\%\end{array}$ & $\begin{array}{l}46 . \\
7 \%\end{array}$ & \\
\hline & & Severe (3) & & & $\begin{array}{c}0.0 \\
\%\end{array}$ & \\
\hline \multicolumn{3}{|c|}{ МCP } & \multicolumn{2}{|c|}{0.584} & 0.437 & \\
\hline
\end{tabular}

a) Measuring the degree of apical straightening (figure 2)

Buccal view: (Table 3)

In Group I (ONESHAPE), sub group I b (circumferential filing) showed higher mean percentage of canal straightening $1.84 \pm 1.93$ than sub group I am (pecking) $1.82 \pm 1.71$ with no statistical significant difference at $\mathrm{P}<0.05(\mathrm{P}=0.836)$ (Table 3). While in Group II, (Revo-S) sub group II b (circumferential filing) showed the highest mean percentage of canal straightening $2.13 \pm 2.05$, while sub group II a (pecking) showed a lower mean percentage $1.91 \pm 1.99$ with no statistical significant difference at $\mathrm{P}<0.05$ $(\mathrm{P}=0.756)$.

By using the Mann Whitney test, the results revealed a non-significant difference at $\mathrm{P}<0.05$ between group I and group II at the buccal view as shown in (Table 3 ).

Proximal view

In Group I (ONESHAPE), sub group I b (circumferential filing) showed higher mean percentage $2.62 \pm 2.25$ of canal straightening than sub group I am (pecking) $1.42 \pm 1.32$ with no statistical significant difference at $\mathrm{P}<0.05 \quad(\mathrm{P}=0.191)$ (Table 3). In Group II (Revo-s), sub group II b (circumferential filing) showed higher mean percentage of canal straightening $2.05 \pm 1.52$ than sub group II a (pecking)
$1.87 \pm 2.01$ with no statistical significant difference at $\mathrm{P}<0.05(\mathrm{P}=0.443)$. (Table 3)

The results revealed a non-significant difference at $\mathrm{P}<0.05$ between group I and group II at the proximal view by using the Mann Whitney test as shown in (Table 3).

The results revealed that circumferential filing in group I and group II caused more canal straightening than pecking motion

in the buccal and proximal views as shown in figure (Figure $3,4)$.

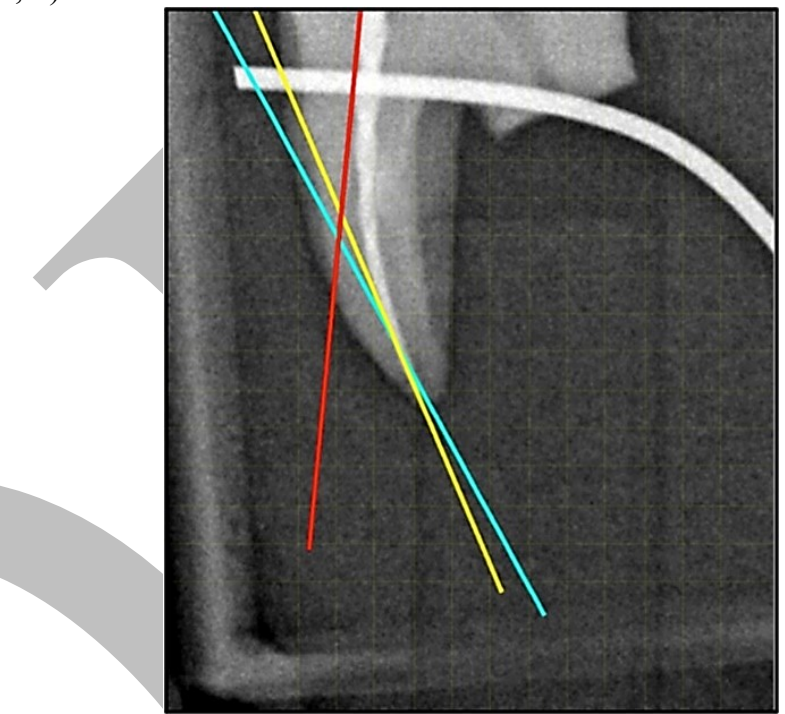

Figure 2: Measuring the degree of apical straightening.

\section{DISCUSSION}

A well-established fact stated that natural teeth show large variations in dentin hardness and root canal morphology, but their use seems to mimic the clinical condition and they are more valid when compared to simulated canals in clear resin block. Although resin blocks have the advantage of standardized root canal shape, size, taper, curvature, but their hardness is completely different from that present in normal dentin.

In the current study curved mesiobuccal root canals of mandibular first molars were chosen, as they are often narrow and have accentuated curves that make debridement and shaping more difficult ${ }^{(11,12)}$. To minimize variables, curvature was standardized to 25-45 degree according to Schneider's technique ${ }^{(8)}$.

Nevertheless, great care was taken to standardize the preparation and evaluation procedures. Aiming to standardize the size of canals before preparation, only canals that could be traversed by size 10 or $15 \mathrm{~K}$-file but resisted passage of size 20 were selected. Also, attention was paid to standardize the tip size and file taper at 25 and $6 \%$ respectively, the Revo$\mathrm{S}$ system was attained by $\mathrm{SU}$ file which matches the OneShape file regarding the tip size and taper. Standardization of the finishing file was important to standardize the final apical preparation size to ensure comparability between the groups ${ }^{(13)}$.

It is also noteworthy that coronal pre-flaring with Endoflare file was done to overcome narrow mesiobuccal canal and to provide a straight-line radicular access. Moreover, coronal pre-flaring allowed more efficient cleaning and shaping, reduced instrumentation time and facilitated more thorough irrigation (14). Furthermore, crowns were maintained to simulate clinical conditions in 
which the interference of cervical dentin projections would create tensions on the files during canal instrumentation ${ }^{(15)}$.

In order to simulate the clinical situation, the working length was not standardized, although similar studies performed standardization of the working length by decoronation ${ }^{(16-18)}$. To assure that variation in the working length did not affect the results, the mean working length of the two groups were compared and no statistical differences were found.

Table (3): Comparison of canal straightening between the test groups in buccal and proximal views (mean degree of apical canal straightening and SD).

\begin{tabular}{|c|c|c|c|c|c|c|c|c|}
\hline \multirow{4}{*}{ View } & \multirow{4}{*}{$\begin{array}{c}\text { File } \\
\text { motion }\end{array}$} & \multicolumn{6}{|c|}{ Group } & \multirow{4}{*}{${ }^{{ }^{\mathbf{P}}} \mathbf{P}$} \\
\hline & & & roup I & & & & & \\
\hline & & \multicolumn{3}{|c|}{ Degree of canal straightening } & \multicolumn{3}{|c|}{$\begin{array}{c}\text { Degree of canal } \\
\text { straightening }\end{array}$} & \\
\hline & & Minimum & $\begin{array}{c}\text { Maxim } \\
\text { um }\end{array}$ & $\begin{array}{l}\text { Mean } \\
\text { (SD) }\end{array}$ & $\begin{array}{l}\text { Mini } \\
\text { mum }\end{array}$ & $\begin{array}{l}\text { Maxi } \\
\text { mum }\end{array}$ & Mean (SD) & \\
\hline \multirow[b]{2}{*}{ Buccal } & Pecking & 0.10 & 5.12 & $\begin{array}{c}1.82 \\
(1.71)\end{array}$ & 0.02 & 6.27 & $1.91(1.99)$ & 0.917 \\
\hline & $\begin{array}{c}\text { Circumfe } \\
\text { rential } \\
\text { filing }\end{array}$ & 0.15 & 7.45 & $\begin{array}{c}1.84 \\
(1.93)\end{array}$ & 0.02 & 6.32 & $2.13(2.05)$ & 0.857 \\
\hline & $P$ & \multicolumn{3}{|c|}{0.836} & \multicolumn{3}{|c|}{0.756} & \\
\hline \multirow{4}{*}{ View } & \multirow{4}{*}{ Tool } & \multicolumn{6}{|c|}{ Group } & \\
\hline & & \multicolumn{3}{|c|}{ Group I } & \multicolumn{3}{|c|}{ Group II } & \\
\hline & & \multicolumn{3}{|c|}{ Difference } & \multicolumn{3}{|c|}{ Difference } & ${ }^{\mathrm{U}} \mathbf{P}$ \\
\hline & & Minimum & $\begin{array}{c}\text { Maxim } \\
\text { um }\end{array}$ & $\begin{array}{c}\text { Mean } \\
\text { (SD) }\end{array}$ & $\begin{array}{l}\text { Mini } \\
\text { mum }\end{array}$ & $\begin{array}{l}\text { Maxi } \\
\text { mum }\end{array}$ & $\begin{array}{c}\text { Mean } \\
\text { (SD) }\end{array}$ & \\
\hline \multirow[b]{2}{*}{ Proximal } & Pecking & 0.045 & 3.606 & $\begin{array}{c}1.42 \\
(1.32)\end{array}$ & 0.090 & 7.682 & $\begin{array}{c}1.87 \\
(2.01) \\
\end{array}$ & 0.633 \\
\hline & $\begin{array}{c}\text { Circumfe } \\
\text { rential } \\
\text { filing }\end{array}$ & 0.020 & 8.000 & $\begin{array}{c}2.62 \\
(2.25)\end{array}$ & 0.219 & 4.812 & $\begin{array}{c}2.05 \\
(1.52)\end{array}$ & 0.604 \\
\hline & & \multicolumn{3}{|c|}{0.191} & \multicolumn{3}{|c|}{0.443} & \\
\hline
\end{tabular}

It is also noteworthy that coronal pre-flaring with Endoflare file was done to overcome narrow mesiobuccal canal and to provide a straight-line radicular access. Moreover, coronal pre-flaring allowed more efficient cleaning and shaping, reduced instrumentation time and facilitated more thorough irrigation (14). Furthermore, crowns were maintained to simulate clinical conditions in which the interference of cervical dentin projections would create tensions on the files during canal instrumentation ${ }^{(15)}$

In order to simulate the clinical situation, the working length was not standardized, although similar studies performed standardization of the working length by decoronation ${ }^{(16-18)}$. To assure that variation in the working length did not affect the results, the mean working length of the two groups were compared and no statistical differences were found.

Two rotary nickel-titanium systems were used in the present study: Revo-S system and OneShape file. The Revo-S system consists of three files. The asymmetrical cross-section of the Revo-S files provides a snake like movement to facilitate progression of the instrument toward the apical region of the canal and an upward removal of the generated dentin debris, preventing the obstruction of the grooves within the file for better debridement efficiency and preventing extrusion of debris beyond the instrument tip and apical foramen ${ }^{(5)}$. While the OneShape system consists of only a single sterile instrument, which has a tip size of 25 and constant taper of 0.06 , and is characterized by different cross-sectional designs over the entire length of its working part. Moreover, OneShape file has a variable pitch length along its working part, this design eliminates threading and binding of the instrument ${ }^{(7,13)}$.

Although, the manufacturer recommends using the Revo$\mathrm{S}$ system for the preparation of ten root canals, in the current study it was used to prepare four canals to provide the same cutting efficiency as that of the OneShape file, which could be used to prepare a molar tooth with four root canals without the risk of file fracture ${ }^{(13)}$.

It was noticed that the gradual canal preparation using multiple files in the Revo-S system provided a much easier progression of the files apically without constrain when compared with the single OneShape file system. On the other hand, OneShape files showed resistance to reach the apical third smoothly.

This study was conducted to evaluate the effect of two file systems with pecking or circumferential filing motions after reaching the apex on apical transportation and apical canal straightening. In the current study, the double radiographic superimposition method was used, for grading of apical transportation and measuring the degree of apical straightening.

To allow accurate reproducible pre and post instrumentation radiographs, the radiographic platform was specially fabricated. Exact superimposition was guided by the projected image of the L shaped wire that was glued facing the sensor ${ }^{(19)}$.

It is important to note that transportation occurred toward the outer part of the curve with group I (OneShape) and group II (Revo-S). This was in accordance with several studies who stated that the direction of canal transportation at the end point of preparation was frequently toward the outer aspects of the curve ${ }^{(20,21)}$.

Regarding canal transportation, the findings of this study showed no significant difference between both filing systems; this could be attributed to the same tip size and taper of the SU file of Revo-S system and OneShape file. This is in accordance with Hashem et al ${ }^{(16)}$ who found that there was no significant difference in canal transportation and centering ratio in the apical one to three $\mathrm{mm}$ between Revo-S, Twisted files, ProFile GT series and ProTaper. They also stated that these results might be because the four systems have a non-cutting tip design that allows easy penetration with minimal apical pressure. On the other hand, some studies found statistical significant difference in shaping abilities when using different nickel-titanium instruments in simulated canals, except for the last two $\mathrm{mm}$ ${ }^{(22,23)}$. Moreover, the fact that no significant difference was found in canal transportation might be attributed to the preflaring of the canals ${ }^{(24)}$

In the current study, no significant difference was found in canal transportation, yet circumferential filing resulted in more cases with severe transportation than pecking motion. These results were in accordance with other studies who reported that the use of pecking motion and circumferential filing motion resulted in small magnitude of transportation with no significant difference ${ }^{(18,25)}$. It is important to note that increasing the number of brushing strokes resulted in more dentinal cutting in the direction of those strokes with no significant difference found between the groups at the apical level ${ }^{(26)}$.

On the contrary, Jeon et al ${ }^{(27)}$ reported that repetitive pecking motions at the working length might result in canal transportation because of the tendency of the file to restore its original linear shape and the reaction torque of the root canal wall especially in curved canals.

Regarding the canal straightening, there was no significant difference between OneShape and Revo-S files, when used with pecking or circumferential filing motions. 
However, circumferential filing motion after reaching the full working length resulted in higher mean straightening values than pecking motions in both groups. These results were in accordance with several studies who reported that all instruments maintained the original canal curvature well with no significant differences between the instrument systems. Also the mean straightening values produced by the use of OneShape file with a slight pecking motion were close to those reported in the present study ${ }^{(13,28)}$.

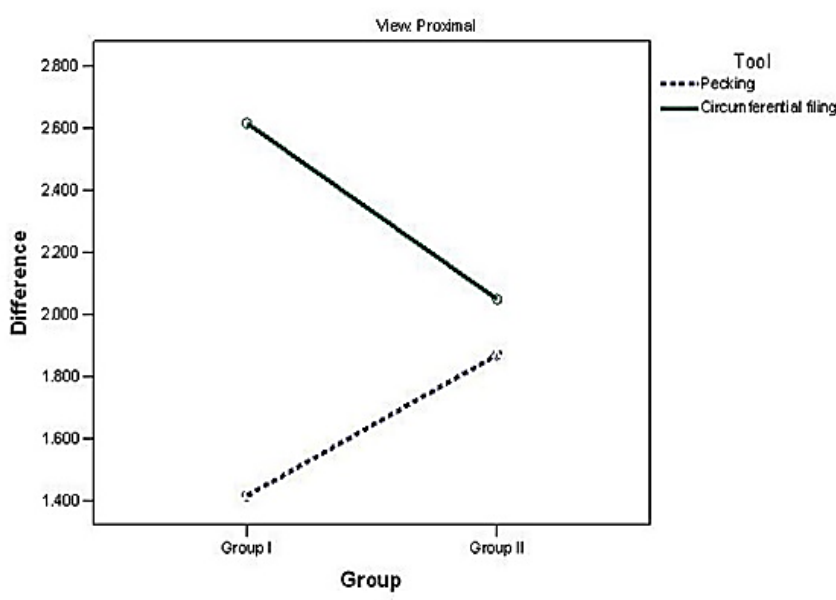

Figure 3: Comparison between group I and II in buccal view in canal straightening.

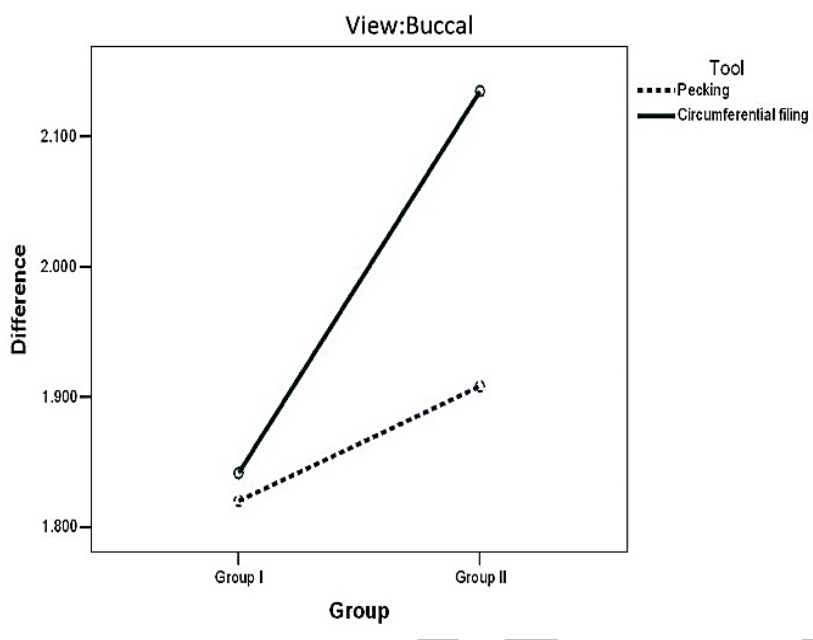

Figure 4: Comparison between group I and II in proximal view in canal straightening.

On the contrary, Burklein et al ${ }^{(29)}$ reported that Revo-S system produced more pronounced canal straightening when compared with Mtwo and Hyflex CM. In addition, Saber et al (30) stated that the use of OneShape instruments with pecking motion resulted in significantly greater canal straightening and apical transportation than WaveOne and Reciproc systems.

It was noticed that as the degree of pre-operative canal curvature increases, as the degree of canal transportation and apical canal straightening increases. Moreover,the more severe the angle and the smaller the radius of the curvature, the more severe the canal transportation ${ }^{(31,32)}$.

\section{CONCLUSIONS}

The hypothesis of this study was found to be true as circumferential filing motion with both systems resulted in higher values of canal straightening when compared to pecking motion but this was not statistically significant.
Pecking motion after reaching the apical limit could be considered safe to finalize the apical preparation.

OneShape file and Revo-S system maintained the original canal curvature well with no significant differences between the different files.

Gradual canal preparation using multiple files in the Revo-S system provided a much easier progression of the files apically without constraint.

\section{ACKNOWLEDGEMENT}

I would like to thank my father and my professors for their continuous support during conduction of this study

\section{CONFLICT OF INTEREST}

The authors declare that they have no conflicts of interest.

\section{REFERENCES}

1. Garcia M, Sindreu F, Mercade M, Bueno R. Comparison of apical transportation between Profile and Race rotary instruments. J Endod. 2012; 38: 990-2.

2. Iqbal MK, Maggiore F, Suh B, Edwards KR, Kang J, Kim S. Comparison of apical transportation in four NiTi rotary instrumentation techniques. J Endod. 2010; 36: 904-7.

3. Ounsi HF, Franciosi G, Paragliola R, Al-hezaimi K, Salameh $\mathrm{Z}$, Tay FR et al. Comparison of two techniques for assessing the shaping efficacy of repeatedly used nickel-titanium rotary instruments. J Endod. 2011; 37: 847-50.

4. Hulsmann M, Peters OA, Dummer PM. Mechanical preparation of root canals: shaping goals, techniques and means. Endod Top. 2005; 10: 30-76.

5. REVO S Brochure. 2009. Available at: http//www.micromega.com.

6. Bonaccorso A, Cantatore G, Condorelli GG, Schafer E, Tripi TR. Shaping ability of four nickel-titanium rotary instruments in simulated S-shaped canals. J Endod. 2009; 35: 883-6.

7. ONESHAPE Files Brochure 2012. Available at: http//www.micro-mega.com.

8. Schneider SW. A comparison of canal preparations in straight and curved root canals. Oral Surg. 1971; 32: $271-5$.

9. Saber M, Nagy M, Schafer E. Comparative evaluation of the shaping ability of Protaper, I RaCe and Hyflex cm rotary Ni-Ti files in severely curved root canals. Int Endod J. 2015; 48: 131-6.

10. Hulsmann M, Styrga F. Comparison of root canal preparation using different automated devices and hand instrumentation. J Endod. 1993; 19: 141-5.

11. Paque F, Musch U, Hulsmann M. Comparison of root canal preparation using Race and Protaper rotary Ni-Ti instruments. Int Endod J. 2005; 38: 8-16.

12. Celik D, Tasdemir T, Er K. Comparative study of six rotary nickel-titanium systems and hand instrumentation for root canal preparation in severely curved root canals of extracted teeth. J Endod. 2013; 39: 278-82.

13. Burklein S, Benten S, Schafer E. Shaping ability of different single-file systems in severely curved root canals of extracted teeth. Int Endod J. 2013; 46: 590-7.

14. Peters OA, Peters CI, Schonenberger K, Barbakow F. Protaper rotary root canal preparation: effects of canal anatomy on final shape analysed by micro CT. Int Endod J. 2003; 36: 86-92.

15. Hashem AA, Ghoneim AG, Lutfy RM, Foda MY, Omar GA. Geometric analysis of root canals prepared by four rotary ni-ti shaping systems. J Endod. 2012; 38: 996-1000. 
16. Rhodig T, Hulsmann M, Kahlmeier C. Comparison of root canal preparation with two rotary $\mathrm{Ni}-\mathrm{Ti}$ instruments: profile .04 and Gt rotary. Int Endod J. 2007; 40: 553-62.

17. Pasternak JB, Sousa-Neto MD, Silva RG. Canal transportation and centering ability of race rotary instruments. Int Endod J. 2009; 42: 499-506.

18. Fayyad DM, Sabet NE, Abd El-hafiz EM. Computed tomographic evaluation of the apical shaping ability of Hero Shaper and REVO-S. ENDO Endodontic Practice Today. 2012; 6: 119-24.

19. Sydney GB, Batista A, De Melo LL. The radiographic platform: A new method to evaluate root canal preparation in vitro. J Endod. 1991; 17: 570-2.

20. Guelzow A, Stamm O, Martus P, Kielbassa AM. Comparative study of six rotary nickel-titanium systems and hand instrumentation for root canal preparation. Int Endod J. 2005; 38: 743-52.

21. You SY, Kim HC, Bae KS, Baek SH, Kum KY, Lee W. Shaping ability of reciprocating motion in curved root canals: a comparative study with micro-computed tomography. J Endod. 2011; 37: 1296-300.

22. Aydin C, Inan U, Gultekin M. Comparison of the shaping ability of twisted files with Protaper and REVO-S nickeltitanium instruments in simulated canals. J Dent Sci. 2012; 7: 283-8.

23. Bürklein S, Börjes L, Schäfer E. Comparison of preparation of curved root canals with Hyflex CM and REVO-S rotary nickel-titanium instruments. Int Endod J. 2014; 47: 470-6.

24. Yared G. Canal preparation using only one Ni-Ti rotary instruments: preliminary observations. Int Endod J. 2008; 41: 339-44.

25. Thompson SA, Dummer PM. Shaping ability of Hero 642 rotary nickel-titanium instruments in simulated root canals: part 2. Int Endod J. 2000; 33: 255-61.

26. Alattar S, Nehme W, Diemer F, Naaman A. The influence of brushing motion on the cutting behavior of three reciprocating files in oval-shaped canals. J Endod. 2015; 41: 703-9.

27. Jeon H, Paranipe A, Ha JH, Kim E, Lee W, Kim H. Apical enlargement according to different pecking times at working length using reciprocating files. J Endod. 2014; 40: 281-4.

28. Elsherief SM, Zayat MK, Hamouda IM. Cone-beam computed tomography analysis of curved root canals after mechanical preparation with three nickel-titanium rotary instruments. J Biomed Res. 2013; 27: 326-35.

29. Bürklein S, Börjes L, Schäfer E. Comparison of preparation of curved root canals with Hyflex cm and REVO-S rotary nickel-titanium instruments. Int Endod J. 2014; 47: 470-6.

30. Saber M, Nagy M, Schafer E. Comparative evaluation of the shaping ability of Waveone, Reciproc and Oneshape single-file systems in severely curved root canals of extracted teeth. Int Endod. 2015; 48: 109-14.

31. Thompson S, Dummer P. Shaping ability of Lightspeed rotary nickel-titanium instruments in simulated root canals. Part 2. J Endod. 1997; 23: 742-7.

32. Peters OA. Current challenges and concepts in the preparation of root canal systems: a review. J Endod. 2004; 30: 559-67. 